\title{
The Implications of Social Networks on the Quality of Accounting Information
}

\author{
Feng $C . X u$
}

\begin{abstract}
:
The information technology (IT) revolution has shown widespread and massive development in communications and social networks, leading to the use of this technology daily. As a result, a number of Accounting features were added and turned into an E-version from a traditional version.

This paper submits a study of the social network's role in growing the quality of accounting information by evaluating it according to distributed questionnaires.

The researchers distributed 20 questionnaires on 20 academic persons and analyzed the results via excel tools, and the main result of this paper is that the Social networks have a big effect on the accounting information because they will build a good background for the accountants.
\end{abstract}

Keywords: Social Networks, Quality, Accounting Information

\section{Introduction}

Social media has to turn out to be a crucial part of our lives. An increasing number of people are already using computers to collaborate and connect. The Internet and its connectivity advantages permit accounting information from a large number of applications that can be used. Email communication, forums for discussion and live chat rooms as well as audio/video conferencing have included the most common uses of the Internet. Social media platforms emerge by communicating via computers and the internet. The use of social network apps to facilitate the growth of online communities in accounting information.

\section{The Quality of Accounting Information}

a) Accounting:

- The Definition:

The main purposes of accounting are protecting the interests of the investments, its owners and other parties involved in business transactions. Where business language is Accounting.

The information is provided to the lender, the debtor, the shareholder government, financial institutions and other related organizations.

The American Accounting Association introduces accounting as "the process of identifying, measuring and communicating economic information to permit informed judgments and decisions by the users of the information", agreeing to AICPA (American Institute of Certified Public Accountants) it is identified as "the art of recording, classifying 
and summarizing in a significant manner and in terms of money, transactions and events which are in part at least of a financial character and interpreting the result".

- Accounting Steps:

The key steps in the accounting process are below:

1. Recording: Recording for the sake of future documentation or reference all activities of subordinate records. It is called the "Journal."

2. Sorting: All transactions recorded in subordinate accounts are categorized and published in the main account book. It's named "Ledger."

3. Summarizing: The preparation of the trial ledger, profit and loss account, and balance sheet will outline all transactions reported in the main accounts.

4. Interpreting: indicates to the meaning and importance of financial and consolidated accounting reports so that business-related parties can determine the future profits of a program with sound dividends, their ability to pay interest, their liquidity, and their competitiveness.

- Functions of Accounting:

The key accounting functions can be outlined from the description and review of the above:

1. Keeping business transactions properly registered.

2. Protection of the company's properties.

3. The reports are transmitted to various parties involved in or relevant to the company.

4. Compliance with regulation.

- Objectives of Accounting:

1. Providing appropriate information to protect the interest rate of the company, its owners and others involved.

2. To concentrate on evaluating and presenting the gains or losses sustained in the product.

3. Determine the financial placement of the entire company.

4. To order and ensure that certain accepted accounting principles and arrangements are formulated to comply with reports.

5. In accordance with Company Act requirements, Revenue Tax Act, etc.

- Branches of Accounting:

The primary role in accounting is to supply information to various ends involved in the wellbeing of that business. Various new accounting branches have been developed to meet the needs of management and externals. The main accounting industries are as follows:

1. Financial accounting: Financial accounting is designed for a specific period to assess a company's performance and financial situation.

2. Cost Accounting: is the formal system of accounting for costs. It is a systemic method in which the cost of the unit for production or service is determined.

3. Management Accounting is interested in providing management with accounting information for active decision-making and monitoring. 


\section{- Principles of Accounting:}

Specific accounting schemes and approaches have been developed to satisfy management needs. The evidence should be collected so that the administrators can reach the right conclusions. The facts should be provided. Management's ultimate goal is to increase profits and losses. It is necessary to file the accounting reports in compliance with accepted standards and practices to achieve the entire goals of the concern. The word standards apply to the code of practice or actions for accounting purposes. The accounting principle can be described as "any rules of conduct or procedures that accountants generally embrace in the reporting of accounting transactions":

1. Accounting Concepts: Concepts of accounting include the required assumptions or presupposition and concepts used for accounting and financial statements. Below are the main accounting principles:

$\checkmark$ Entity.

$\checkmark$ Dual Aspect.

$\checkmark$ Accounting Period.

$\checkmark$ Going Concern.

$\checkmark$ Cost.

$\checkmark$ Money Measurement.

$\checkmark$ Matching.

$\checkmark$ Realization.

$\checkmark$ Accrual.

$\checkmark$ Rupee Value.

2. Accounting agreements: includes these rules, processes, and standards as guidance for planning the accounting reports to be implemented. The accounting arrangements can be classified as follows:

$\checkmark$ Disclosure.

$\checkmark$ Conservatism.

$\checkmark$ Consistency

$\checkmark$ Materiality.

b) Accounting Information:

The information market in the accounting sector actually responds to this particular market demand and supply. The need for accounting knowledge is determined by customer requirements and the accounting system pressure. The accounting information collected within the financial system and the means of disseminating this information are given in the offering of accounting information. As the financial accounting information functions an important role as a "social good" today, accounting has unified its placement within an entity's information system, despite being public or private, clearly contributing "to complex social, multilateral and multidimensional relations." The goals of financial accounting information are in theory linked to the knowledge the consumers have - the need to make decisions.

The reportage of the user's demands is the main prerequisite for determining the objectives of any information system, given that the detection of accounting information goals and the user's requirements are always closely related. 
On the one hand, consumers primarily require information to direct their decision-making procedures, which in turn allow effective controls to be exerted on the execution of legal obligations and productive resource management. I shall evaluate the consistency of the accounting information and the specific information demands of the accounting information consumers, depending on the above-mentioned issues.

The basic requirements for the consumers of accounting information are given after the collection and analysis of the data using a variety of accounting methods and practices that demonstrate the economic reality of an organization based on a number of accounting principles and definitions. According to current regulations, expert accountants provide accounting information.

A number of factors, including standardizing the accounting system, the quantity, and quality of the accounts information and cost of production, disseminating and working with information, apply to both the demand and provision of accounting information. Useful information on financial accounting has to satisfy two fundamental qualitative characteristics to meet its objective, the user needs relevance and real representation. Relevance believes that users need the information to support their economic choices so that it must be subscribed and can create a difference in users' choices. The financial information provided in the annual reports will influence decisions of forecast value, verifying value or both. The information is important if its distraction or failure could, on the basis of the financial statements, affect users ' economic decisions. The materialistic threshold is very important and introduces a limit that is no longer relevant to the information. A financial accounting record must be complete, impartial and error-free to be an accurate representation. All information and declarations are necessary for the user to understand the described phenomenon is provided in full description. A fair definition cannot affect financial information collection and delivery. An error-free definition has been chosen and implemented, without error in the process, in which no errors or omissions exist in the explanation of the phenomenon, while the method used to produce the details recorded.

As much as these essential qualitative qualities, compatibility, verification promptness, and understandable consideration must also be provided since they are qualitative characteristics that improve and exactly reflect the utility of the relevant information. Comparability means that the information contained in the financial statements should be comparative in due course is capable to assess financial patterns and the results of the company. Control helps ensure that users accurately present the information to the economic phenomena they intend to describe.

Verifiability involves the consensus of numerous independent and competent experts that a given statement is an accurate description. Timeliness ensures that if the processing of reports is unnecessarily postponed, the data may lack its importance, and administrators may choose to include trustworthy information between the relative value of the reporting in a given time. Intelligibility means that users with limited background on accounting principles, and understanding of business and economic practices can easily understand the information provided by the financial statements.

They can be clearly and concisely defined, described and categorized by details. As for the factors which affected the information management activities in the financial statements, there are a variety of factors which we can cite: environment, regulation, political systems, 
economic control, the social climate, accounting rules for stability, economic growth, education, etc.

The identification and presentation of external elements that affect an entity will probably influence both the provision of accounting information and the quality of the information provided by the entity. At the same time, internal influences affect the way the accounts are handled and influence their consistency in the company's approach.

\section{Accounting information demands of users:}

The Accounting Information group can be categorized as follows: - accounting information users within an organization: members, the board of directors, staff; external accounting users: investor, investor, supplier, consumer, official, state and other entities. . accounting information users outside an entity.

In order to sustain their future decisions, the founders, board of directors and employees want to know about the viability and competitiveness of their business. The shareholders and the board of directors are especially attentive in the potential of the company to generate profit, while employees are keen to provide the firm with remuneration, insurance, and other rewards as well as professional opportunities.

In order to decide the acquisition, selling or holding of securities, and to allow the company to pay incomes in order to measure the internal returns of rate on investment, existing or prospective creditors are involved in the risk-benefit partnership.

The financial borrowers are interested in information on the repayment capacity of the company, in their due dates, in the financial obligations to determine whether the number of loans or loans given or the recovery of the loans granted or to break any arrangement with the institution to raise, decrease or constant retain.

Suppliers and other trade borrowers are involved to establish solvency of the company, as well as to agree on the maturity of the amounts owed, such as forming trading bonds, sustaining, improving or deteriorating business relations, granting or canceling trade facilities. Clients are mindfully in information concerning the continuity of the company's activities in deciding on: the long-standing cooperation with the company, failure to establish a commercial relationship with it, search for other providers when customers depend on it.

The details that can determine the economic and social effect of the operation of the company is of concern to the public. State institutions and other bodies need a broad spectrum of knowledge to control the operations of the companies, develop taxes, quantify national and other macroeconomic notations, evaluate the environmental impact of the business operation, etc. It is the management of the entity, which is able to identify the shape and content that is responsible for the preparation and submission of the financial statements. In addition to data from the financial statements, managers of the entities have access, in order to draw up the planning, decision-making and control processes, to additional financial and management information. While not fulfilling all user information demands, financial statements satisfy the basic desires of their majority.

It can be said as the financial statements primarily depict the financial impact of certain previous events and do not necessarily include non-financial information.

Furthermore, the financial statements show the company management findings, including its management method of managing the resources dependent on the company. The focus on 
financial statements is influenced by conflicts of interest that exist in the accounting information industry in terms of the presence of three individuals, businesses, customers and accounting practices. The companies are the subject of financial information and also of a specific degree of relevance to the supplier of financial statements. The consumers request the details and control the output of accounting results. The accounting sector has a role to play in developing the financial statement quality.

* The limits on accounting information obtained from the Annual financial statements Some knowledge shortcomings resulting from the limitations on information contained in the financial statements are encountered by the receivers of accounting records which can be outlined as follows; the historical expense of these deficiencies, paid, is the most important calculation metric for the elements. Some financial statement knowledge is arbitrary because it is focused on estimations of different dimensions for the constituent factors and structures of the financial statement. The presence and freewill of accounts contribute to creative accounting skills which are capable of producing the reports and not the actual information; a partnership between accounting and fiscal services also contributes to the inconsistencies of the financial statements ' records; because certain information is not deemed to be monetarily commensurate (such as for example the entity able to create profit or the risks it could underlie is not fully clarified in any financial statement component.

C) The quality of accounting information:

Siegel (1982) cited: "Quality appears to be an important attribute of accounting information. However, accounting quality is neither a readily measurable nor a generally agreed-upon characteristic of a firm." Ten years later, Imhoff (1992) noted the significance of Siegel and added that the term accounting consistency suggests that, because of bias or measures errors or the two, all accounting signals should not be entirely noise-free. From this definition, accounting quality can be derived from accounting signals that can be traced back to financial reporting. It should be noted that the quality of accounting in this study is described by the quality of financial reports. Hoogendoorn and Mertens (2001) agree that communication is the subject of financial reporting. In particular, it is necessary for the stakeholders with a financial interest in an organization to share financial and not financial information. The aim of this analysis is to provide external financial reports to the owners of an organization. The quality of financial reporting is linked to the stakeholders for whom this information is primarily intended. Stakeholders should be able to use the details for their decision-making in financial reports. "Better the usefulness of financial information to make decisions, greater the quality of financial information." The value of good accounting quality is related to this argument. The statement also states that financial information is more important in decision-making. High-quality accounting provides useful information that allows participants to choose the best and improve the efficiency of the capital market. In response to this claim, Frankel and $\mathrm{Li}$ (2004) point out the accounting principle that financial reporting often eliminates asymmetry by sharing relevant information in a timely manner.

Soderstrom and Sun 2007 explains the scheme that defines the controlling determinants of accounting efficiency. Where figure (1) demonstrates that the quality of the accounts, incentives for financial reporting, accounting standards are all affected by legal and political 
systems. While accounting standards can affect financial reporting, the total accounting performance is calculated by only one factor.

Since the legal and political structure and requirements for financial reporting tend to vary between countries, accounting standards can vary from country to country. Therefore, the various determinants of accounting quality require detailed country-specific explanations when studying accounting quality.

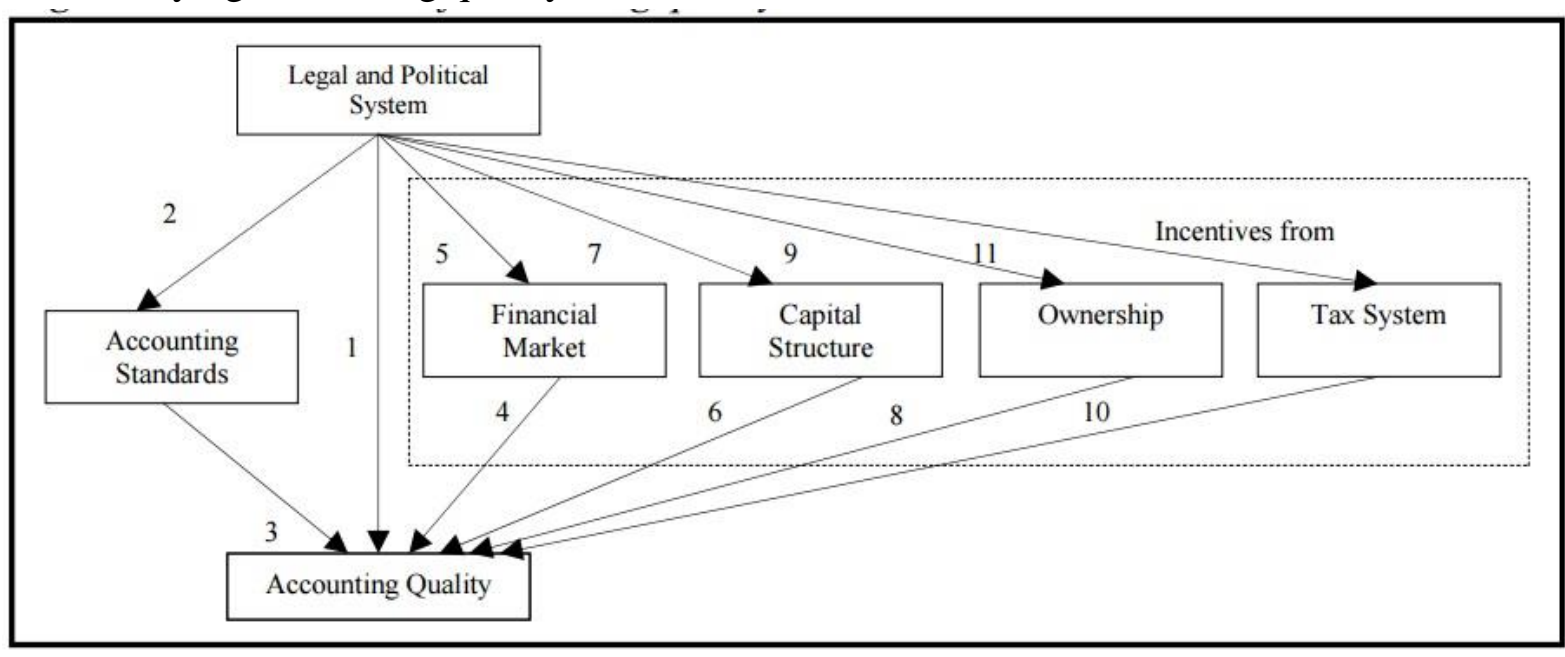

Fig. (1): Legal and policy influence

\section{The Social Network}

\section{Definition:}

Social networks are an individual's (or organizations) social terminal system and their associations within a certain area. Social networks are thus usually built on relationships and trust between members (nodes). The methods of linking these nodes have been studied and different types of interactions between nodes are established. Many researchers describe a web-based social network, allowing individuals to create a public or semi-public profile within a restricted structure, list other users they have a connection to, display and cross their ties and those of others in the system. Such relations can differ in definition and nomenclature from place to place.

\section{Historical Background:}

In the late 1890s, Émile Durkheim and Ferdinand Tönnie discussed the idea of social networks in their studies and research groups. Tönnies proposed that social groups could function as direct or individual social links between people who share (community) values and beliefs, or as impersonal, structured and social links to instruments (society). Tönnies further argued that social groups are relational as people that share common values and beliefs.

Durkheim offered a non-individualist interpretation of social reality, arguing that social phenomena occur as people interact, as a result of which the property of individual actors is not responsible anymore. Writing at the turn of the $21^{\text {st }}$ century, Georg Simmel pointed to the network nature and effect of network size on interaction and studied the possibility of contact in loosely-tuned networks instead of communities.

In the 1930s, numerous researchers in psychiatry, sociology, and mathematics collaborated independently to explain major developments in the field.

In psychology, in particular, in the classrooms and working groups of the 1930s, Jacob L. 
Moreno began to record and analyze social interacting in small groups. The social theory is based in sociology on the theoretical and ethnographical work of Bronislaw Malinowski, Alfred Radcliffe-Brown and Claude Lévi-Strauss.

Several of these areas of network analysis and group networks in South Africa, India, and the UK are often considered to be performed by some social anthropologists, including John A. Barnes, Clyde Mitchel and Elizabéth Bott Spillius, who has been affiliated with Max Gluckman and Manchester University. The UK Anthropologist S.F. Concomitantly In later networking, Nadel codified a theory of social structure. Through sociology, Talcott Parsons ' early (the 1930s) research laid the way to a new approach to social comprehension. Through Parson's theory, sociologist Peter Blau later gave a strong impetus to his work on social exchange theory to analyze the relationship of social units. By the 1970s, more and more physicists sought to merge different routes and customs. Sociologist Harrison White and collaborators in the Social Relations Department at Harvard University were also members of another group. The social relations at Harvard were also self-interested by Charles Tilly, who focused on networks within sociological and social movements and within national and cultural societies, as well as by Stanley Milgram, who proposed the "six-degree separation" principle. Former White students are Mark Granovetter and Barry Wellman, who developed and championed social network analysis.

3. Props and Cons:

The social network is nowadays very popular and has major effects on people's lives. The social networking controversy has appeared throughout the world. There are some who condemn it, but there are also many who are in favor of it because we have shown the social network advantages and disadvantages.

- The Advantages:

1. It helps people to be very relaxed in contact with their relatives and friends from distant.

2. Social networking is a popular way of promoting goods and services.

3. For someone expressing themselves on the internet, it can be a perfect medium.

4. Social networking may help charitable organizations or charities meet their needs and support others.

5. Social networking is an advanced search engine for job seekers locally and internationally.

6. It could be a way of fighting organized crime or probably terrorism.

7. Social networking can be the best way to search for friends, schedules or even individuals in need of lost animals and family.

8. It can use political will to make institutions more open to the public.

9. People looking for ideas and thoughts on a certain topic can also rely on social networking to ask for possible answers.

- The Disadvantages:

1. Social networking can take considerable time to engage in other important activities, such as family connections.

2. As their only form of communication, many people use social networks. Want happy birthdays on the walls rather than personally or on the phone.

3. It can create a great barrier between those who have Internet access and those who do not.

4. Due to social media, your privacy is in big jeopardy and can harm your personal 
dignity and pride.

5. Social networking can have a huge impact on public policy and can lead to many changes.

6. It can also be a form of destabilizing the nation and a means of advanced violence.

7. It can be used for crime prevention.

8. It's a perfect venue for intimidation that is nowadays very obvious.

9. The structure of a particular language can be ruined by it. Many people post comments and thoughts and they tend to simplify the language, which can lead to a serious language problem because of the time factor.

10. It can deter someone from moving freely if they have had a poor social networking experience. For example, someone is a victim of bullying by social networking.

\section{Relationship between social network and accounting information}

In the process of learning, there are four typical activities of learning:

- Creation of content information: Students were able to create ideas and work for the public. Such exercises also allow students to create and share their knowledge with their learning community.

- Sharing of information: This activity enables the content that is learned to be improved and extended.

- Interactions: The interactive process includes student interactions leading to active debate. You can leave your comments or reviews on the panels and expect detailed comments on certain topics.

- Social partnership: It includes cooperation with the social network to address a certain problem.

\section{The use of social media as accounting information platforms}

Social media was fundamentally organized into a system composed of people, groups, businesses, and organizations, and in the field of e-learning this framework can be applied in several various ways through tools, such as:

\section{Facebook}

The teacher will create a group without effort, either closed or opened, for sharing in an individual course or module content, ideas, queries, resources, images or even an entire class. Students will freely speak about various courses, questions, knowledge about each other and issues they want to discuss in general.

\section{Twitter}

In e-learning, it can be used as a backbone for connecting learning communities or small classrooms over a certain subject or event, for sharing highlights, making a statement, uploading photos, etc. All instructors must create an account and give their \# hashtag to their students.

\section{LinkedIn}

This is a purely professional, but still social, e-Learning network which proved extremely useful. There are currently thousands of discussions and group discussions in different languages with teachers, educators and influences sharing opinions, challenges, developments and tips on how to do so. Compared with previous social platforms, it has an even higher value, because students/participants can see the professional profile and achieving's of everyone, something which normally decides the rank of the chief, organizer or expert.

Google Plus

Google Plus is a virtual networking rebellion center. Many e-learners, like me, are optimistic 
that Google Plus will be the most popular social platform for learning. How, however? Google+ groups are commonly used as networking sites, and one of the major reasons is the less depressed presence of both learners and facilitators from Facebook and Twitter. Ronald L has made an interesting point: "Students do not want to research on their social networks. You want to keep a separate private and professional life. Last but not least, I strongly agree with Steve Rayson that "G+ is the best social media site for social learning because it has the potential to host video static networks, reviews, and google hangouts."

\section{YouTube}

A strong e-learning aid. It is free and is eligible for a class, while audiences can also rate the content, rating, and opinion of the film. Such videos can be included in a lesson, but professors can also use this content to show entire tuition or just teasers in order to attract viewers.

\section{Practical Section}

In this paper, a sample of twenty questionnaires have been written and circulated to an accountancy slide-based in Erbil for purposes of this study the questionnaire consisted of two sections, firstly the content of the knowledge on accounting, and secondly, the social network.

The researchers have compiled and analyzed the responses from twenty questionnaires using the Fuzzy and MatLab 2017 logic processes.

\section{The questionnaire}

As shown in Table 1 and Table 2 the questionnaire contained two parts with ten questions each.

TABLE 1 THE FIRST QUESTIONNAIRE PART

\begin{tabular}{llc}
\hline $\mathbf{S}$ & \multicolumn{1}{c}{ QUESTION } & CODE \\
\hline $\mathbf{1}$ & The duration of the accounting use of the social network. & $\mathrm{Q}_{1}$ \\
$\mathbf{2}$ & The number of hours of login. & $\mathrm{Q}_{2}$ \\
$\mathbf{3}$ & The number of hours to browse & $\mathrm{Q}_{3}$ \\
$\mathbf{4}$ & $\begin{array}{l}\text { The transmitting or reception of accounting data through social media for } \\
\text { accountants. }\end{array}$ & $\mathrm{Q}_{4}$ \\
$\mathbf{5}$ & The method used in accounting for social media. & $\mathrm{Q}_{5}$ \\
$\mathbf{6}$ & The number of hours in accounting use of social media. & $\mathrm{Q}_{6}$ \\
$\mathbf{7}$ & The advantage of accounting by the use of social media. & $\mathrm{Q}_{7}$ \\
$\mathbf{8}$ & The number of social network accounting classes. & $\mathrm{Q}_{8}$ \\
$\mathbf{9}$ & The kind of social network accounting pages. & $\mathrm{Q}_{9}$ \\
$\mathbf{1 0}$ & Social networking operation to enhance accounting information. & $\mathrm{Q}_{10}$ \\
\hline
\end{tabular}

TABLE 2 THE SECOND QUESTIONNAIRE PART

\begin{tabular}{clc}
\hline $\mathbf{S}$ & \multicolumn{1}{c}{ Question } & \multicolumn{1}{c}{ Code } \\
\hline $\mathbf{1}$ & The period of social network usage. & $\mathrm{I}_{1}$ \\
$\mathbf{2}$ & Login times total. & $\mathrm{I}_{2}$ \\
$\mathbf{3}$ & The number of hours of browsing. & $\mathrm{I}_{3}$ \\
$\mathbf{4}$ & The teachers that send or receive from social media students. & $\mathrm{I}_{4}$ \\
$\mathbf{5}$ & Use of e-mail applications. & $\mathrm{I}_{5}$ \\
$\mathbf{6}$ & The time spent on social media. & $\mathrm{I}_{6}$ \\
$\mathbf{7}$ & The advantage of social media access. & $\mathrm{I}_{7}$ \\
$\mathbf{8}$ & The number of the social network science community. & $\mathrm{I}_{8}$ \\
$\mathbf{9}$ & The social network sort of sites. & $\mathrm{I}_{9}$ \\
\hline
\end{tabular}


10 The social network activity.

Fuzzy logical tools were used to process the results of this questionnaire for the twenty samples, the results of the analysis being shown in Table 3.

TABLE 3 THE FINDINGS FROM THE FIRST AND SECOND PARTS OF THE QUESTIONAIRE.

\begin{tabular}{ccccc}
\hline $\mathbf{S}$ & $\mathbf{Q}$ & $\mathbf{\%}$ & $\mathbf{I}$ & $\mathbf{\%}$ \\
\hline $\mathbf{1}$ & $\mathrm{Q}_{1}$ & $12 \%$ & $\mathrm{I} 1$ & $22 \%$ \\
$\mathbf{2}$ & $\mathrm{Q}_{2}$ & $14 \%$ & $\mathrm{I} 2$ & $30 \%$ \\
$\mathbf{3}$ & $\mathrm{Q}_{3}$ & $22 \%$ & $\mathrm{I} 3$ & $44 \%$ \\
$\mathbf{4}$ & $\mathrm{Q}_{4}$ & $15 \%$ & $\mathrm{I} 4$ & $27 \%$ \\
$\mathbf{5}$ & $\mathrm{Q}_{5}$ & $10 \%$ & $\mathrm{I} 5$ & $33 \%$ \\
$\mathbf{6}$ & $\mathrm{Q}_{6}$ & $25 \%$ & $\mathrm{I} 6$ & $41 \%$ \\
$\mathbf{7}$ & $\mathrm{Q}_{7}$ & $30 \%$ & $\mathrm{I} 7$ & $37 \%$ \\
$\mathbf{8}$ & $\mathrm{Q}_{8}$ & $22 \%$ & $\mathrm{I} 8$ & $32 \%$ \\
$\mathbf{9}$ & $\mathrm{Q}_{9}$ & $26 \%$ & $\mathrm{I} 9$ & $28 \%$ \\
$\mathbf{1 0}$ & $\mathrm{Q}_{10}$ & $16 \%$ & $\mathrm{I} 10$ & $29 \%$ \\
\hline
\end{tabular}

Figure 1 and Figure 2 Display the analyzed findings in graphical maps of the twenty questionnaires.

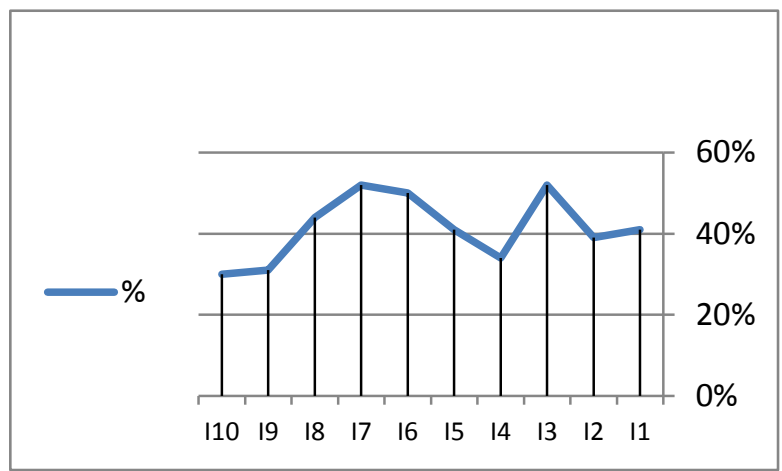

Fig. 1 The first part of the questionnaire is a linear diagram.

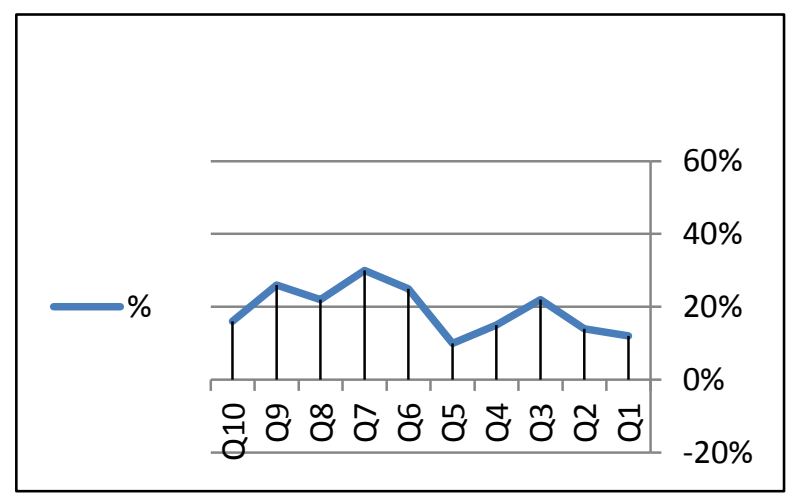

Fig. 2 The second part of the test is a linear chart.

\section{Conclusions:}

The researchers can assume from the results:

1. The use of social networks and the accuracy of accounting information are in close relation to each other.

2. Using the social network will improve the accountants ' expertise. 
3. Because of the use of the social network the computer skills of users have improved fully.

4. When the accountant uses social media, the accuracy of accounting information would dramatically improve.

5. Accounting information users should give special attention to accounting as the identification and description in financial statements of all the business and financial transactions in the company play an essential role in financial communication.

\section{References:}

1. Al-Delawi, Amjad S. (2015). Activating Accounting Information System in Light of Electronic Trade in Iraq, AL-Anbar University journal of Economic and Administration Sciences, 7(13).

2. Al-Delawi, Amjad S. (2019). Role of ethics in Islamic Thinking in the activation of accounting information quality, Utopía y praxis latinoamericana: revista internacional de filosofía iberoamericana y teoría social, 6, 179-187.

3. Al-Delawi, Amjad S., Ramo, Waheed M. (2020). The Impact of Accounting Information System on Performance Management, Polish Journal of Management Studies, 21.

4. Al-Nasrawi, Salam A., and Thabit, Thabit H. (2020). The Influence of the Environmental Factors on the Adoption of the International Accounting System IAS/IFRS: Case of Iraq, Journal of Accounting, Finance and Auditing Studies, 6(1), 66-85.

5. Bernstein, L., and Wild, J. (2000). Financial Statement Analysis: Theory, Application and Interpretation, New York: McGraw-Hill Companies, Inc.

6. Bodie, Z., Kane, A., and Marcus, A. (2004). Essentials of Investments, $5^{\text {th }}$ ed., McGraw-Hill.

7. Dawood, Harith A., Thabit, Thabit H., Jasim, Yaser A. (2015). Proposed Approach to Apply a Green Balanced Scorecard at the Iraqi Environment, 2nd International Conference on Ecology, Environment, and Energy, Ishik University, Erbil, Iraq.

8. Dufera, A. (2010). Financial Performance Evaluation (A Case Study of Awash International Bank (AIB)), Mekelle University, Mekelle, Ethiopia.

9. Epstein, Barry J., and Jermakowicz, Eva K. (2007). Interpretation and Application of International Financial Reporting Standards, John Wiley \& Sons.

10. Helfert, Erich A. (2010). The Nature of Financial Statements: The Cash Flow Statement, Financial Analysis - Tools and Techniques - A Guide for Managers.

11. Jasim, Yaser A., and Raewf, Manaf B. (2020). Information Technology's Impact on the Accounting System, Cihan University-Erbil Journal of Humanities and Social Sciences 4 (1), 50-57.

12. Jasim, Yaser A., Awqati, Ali J., Hussen, Russel A., and Lubis, Nurul Izzah (2020). Job Costing: Empirical Evidence of Bakery Production, Accumulated Journal (Accounting and Management Research Edition), 2(2), 179-189.

13. Kieso, D., Warfield, T., and Weygandt, J. (2010). Balance Sheet \& Statement of Cash Flows, Intermediate Accounting, JohnWiley \& Sons, New Jersey, USA.

14. King, Alfred M. (2006). Fair Value for Financial Reporting, New Jersey, John Wiley \& Sons. 
15. Lefebvre, R., Simonova, E., and Scarlat , M. (2009). Fair Value Accounting: The Road to Be Most Travelled, Issue in focus, Certified General Accountants Association of Canada, CGA.

16. Leone, M. (2009). The FAS159 Mulligan, CFO Magazine.

17. Neely, M.C. and Wheelock, D.C. (1997). Why Does Bank Performance Vary Across States?, Federal Reserve Bank of St. Louis Review, 79(2).

18. O'Kelly, B. (2008). Commercial Banks: How Fair is Fair Value?, Accountancy Ireland, 40(3).

19. Pannese, D. and Delfavero, A. (2010). Fair Value Accounting: Affect on the Auditing Profession, Journal of Applied Business Research, 26(3).

20. Peters, D., Raad, E., and Sinkey, F. (2004). The Performance of Banks in Postwar Lebanon, International Journal of Business, 9(3), 259-28.

21. Ronen, J. (2002). Post-Enron Reform: Financial Statement Insurance and GAAP Revisited, Stanford Journal of Law, Business and Finance, 8(1).

22. Ross, S. A., Westerfield, R. W, and Jaffe, J. (2005). Corporate Finance. McGraw-Hill Inc., $7^{\text {th }} \mathrm{Ed}$.

23. Saleh, A. S., and Z. Rami (2006). Islamic Banking Performance in the Middle East: A Case Study of Jordan, Working Paper 06-21, Department of Economics, University of Wollongong.

24. Samad, A., and Hassan, K. (2000). The Performance of Malaysian Islamic Bank During 1984-1997: An Exploratory Study, Thoughts on Economics 10(1).

25. SBDC (2004). Financial Statement Analysis for Small Businesses: A Resource Guide, Virginia Small Business Development Center Network, USA.

26. Sheikh Waqas, A. (2005). Financial Statement Analysis of Bank Falah, Virtual University Pakistan, Pakistan.

27. Thabit, Thabit H. (2019). The Influence of Mobile Information Technologies in Enhancing the Electronic Audit, The $3^{\text {rd }}$ International Scientific Conference, The World Islamic Sciences and Education University, Amman, Jordan.

28. Thabit, Thabit H., Aldabbagh, Lukman M., and Ibrahim, Laith K. (2019). The Auditing of Sustainable Development Practices in Developing Countries: Case of Iraq, Revista AUS, 26(3), 12-19.

29. Thabit, Thabit H., and Abbas, Nazar H. (2017). A Proposed Fuzzy Logic Based Framework for E-Accounting: Evaluation in Iraq, Qalaai Zanist Scientific Journal, 2(6), 732-751.

30. Thabit, Thabit H., and Al-Nasrawi, Hamed A. (2016). The Role of International Financial Reporting Standards in Reducing the Financial Risks, International Journal of Latest Engineering Research and Applications, 1(5), 73-82.

31. Thabit, Thabit H., and Jasim, Yaser A. (2016). A Manuscript of Knowledge Representation, International Journal of Social Sciences \& Economic Environment, 1(1), 44-55.

32. Thabit, Thabit H., and Jasim, Yaser A. (2016). The Role of Environmental Accounting Disclosure to Reduce Harmful Emissions of Oil Refining Companies, The $3^{\text {rd }}$ International Conference on Energy, Environment, And Applied Science, Ishik University, Erbil, Iraq.

33. Thabit, Thabit H., and Jasim, Yaser A. (2017). Applying IT in Accounting, Environment and Computer Science Studies, LAP- Lambert Academic Publisher, Germany. 
34. Thabit, Thabit H., and Jasim, Yaser A. (2019). The Challenges of Adopting EGovernance in Iraq, Current Research Journal of Social Sciences and Humanities, 2(1), 31-38.

35. Thabit, Thabit H., and Raewf, Manaf B. (2016). The Impact of Voluntary Disclosure on SMEs in Developing Countries, Journal of Global Business and Social Entrepreneurship, 4(5), 19-31.

36. Thabit, Thabit H., and Raewf, Manaf B. (2017). Applications of Fuzzy Logic in Finance Studies, LAP- Lambert Academic Publisher, Germany.

37. Thabit, Thabit H., and Raewf, Manaf B. (2018). The Evaluation of Marketing Mix Elements: a Case Study, International Journal of Social Sciences \& Educational Studies, 4(4), 100-109.

38. Thabit, Thabit H., and Solaimanzadah, Alan (2018). The Role of SOX Act in Enhancing the Internal Control Systems of Kurdistan Banks, International Conference on Accounting, Business, Economics and Politics, Ishik University, Erbil, Iraq.

39. Thabit, Thabit H., Hadj Aissa, Sid A., and Harjan, Sinan A. (2016). The Use of Fuzzy Logic to Measure the Risks of ICT in E-Audit, Revue des Recherches Economiques, No.15, pp. 30-46.

40. Thabit, Thabit H., Hadj Aissa, Sid A., and Jasim, Yaser A. (2021). The Impact of Green ICT Adoption in Organizations of Developing Countries, Al-riyada for Business Economics Journal, 7(1), 9-18.

41. Thabit, Thabit H., Ibraheem, Laith K., and Majed, Ahmed W. (2019). Proposed Framework for Auditing Sustainable Development Practices in Iraq, $8{ }^{\text {th }}$ International Scientific Conference, Baghdad College of Economic Sciences University, Baghdad, Iraq.

42. Thabit, Thabit H., Ishhadat, Heba S., and Abdulrahman, Omar T. (2020). Data Governance Based on COBIT2019 Framework to achieve Sustainable Development Goals, Journal of Techniques, 2(3), 9-18.

43. Thabit, Thabit H., Solaimanzadah, Alan, and Al-abood, Muath T. (2017). The Effectiveness of COSO Framework to Evaluate Internal Control System: The Case of Kurdistan Companies. Cihan International Journal of Social Science, 1(1), pp. 44-54.

44. Thabit, Thabit H., Solaimanzadah, Alan, and Mohammed, Mohammed A. (2019). Determining the Effectiveness of Internal Controls in Enterprise Risk Management based on COSO Recommendations, the $2^{\text {nd }}$ International Conference on Accounting, Business, Economics and Politics, Ishik University, Erbil, Iraq.

45. Veron, N. (2008). Fair Value Accounting is the Wrong Scapegoat for This Crisis, Revue d'Economie Financière and Risques. 